\title{
Organizational Form and Expense Preference: Spanish Experience
}

\author{
Iftekhar Hasan \\ New York University \\ Stern School of Business \\ 44, West $4^{\text {th }}$ Street, 9-190 KMEC \\ New York, NY 10012 \\ (212) 998-0329 \\ (212) 685-7535 (F) \\ e-mail: ihasan@stern.nyu.edu \\ and \\ Ana Lozano \\ Departamento de Teoria Economica \\ Facultad de Economicas \\ Universidad de Malaga \\ Malaga, Spain \\ $34952131256(\mathrm{O})$ \\ $34952131299(\mathrm{~F})$ \\ e-mail: lozano@correo.vnet.es
}

Novemeber, 1999

The authors would like to thank Allen Berger, Robert DeYoung, Loretta Mester, Jesus Pastor, and participants of the European Productivity Workshop in Copenhagen and INFORMS meeting in Barcelona, Spain. 


\section{Organizational Form and Expense Preference: Spanish Experience}

Abstract - This article investigates the effect of alternative ownership structures, stock versus mutual, on the cost of production of Spanish depository institutions. The empirical approach adjusts for the possibility that the two sectors of the banking industry employ different production technologies and find evidence that is consistent with the expense preference behavior by the mutual savings banks.

\section{INTRODUCTION}

A number of papers [Williamson (1963), Leibenstein $(1966,1975)]$ in the literature argued against the traditional neoclassical assumption that firm management is primarily driven by profit maximization goals, especially in an environment where there is a separation of ownership and control of firms; less competitive and inefficient markets; and a high degree of regulatory structure. These papers, in general, have suggested that managers might pursue the strategy of maximization of personal utility by favoring excessive allocation of resources in salaries, a larger staff, unnecessary perks, privileges, and office settings. Among others, Edwards (1977), Hannan (1979), Hannan and Mavinga (1980), Verbrugge and Goldstein (1981), Verbrugge and Jahera (1981) found consistent evidence of such expense preference behavior in the United States depository industries; Awh and Primeaux (1985) in the electrical utility industry; and Fields (1988) in the mutual life insurance companies.

However the above findings are however conclusive as Rhoades (1980), Smirlock and Marshall (1983), Blair and Placone (1988), Mester (1989), Stansell and Hollas (1990), and Carhill and Hasan (1997) provided evidence inconsistent with expense-preference behavior among the U.S. banks and saving and loans (S\&Ls). Using S\&L data, Mester (1989) as well as Stansell and Hollas (1990) argued that the supporting evidence of expense-preference behavior found in previous papers was flawed from inappropriate estimation approach and, once the estimation approach was corrected, no 
such evidence was found. The popularity of using S\&L data is not surprising as the industry provides a good opportunity to compare institutions with both the mutual and stock forms of organizations. Unlike stock institutions, the mutual form of organizations do not undergo direct monitoring or profitmaking pressure from stock holders (owners), and, therefore, their managers may have different goals and strategies.

This paper provides additional evidence for the existing debate on expense preference in the depository industry and attempts to bring new perspectives to the literature. First, this note uses data from the Spanish depository industry which consists of both mutual and stock types of institutions. This is the first inquiry into such issues in the Spanish as well as the European banking industry. A high percentage of European banks are the mutual type and the increasing merger and acquisition mania in the European banking industry warrants a better understanding of these institutions relative to the stock form of orgnizations. Second, the note introduces a stochastic or econometric frontier estimation approach to capture the extent of expense preference by these two sectors of the banking industry. Although this methodology is used extensively in the banking literature, its specific application in the expense preference literature is new. ${ }^{1}$ Third, the note presents a broader perspective of expense practices by focusing not only on noninterest expenses but also on the patterns of interest expenses. This additional comparison provides an opportunity to see whether spending patterns of institutions with different organizational forms is consistent across different segments of businesses. Moreover, for further insight into the expense-preference sources, the paper decomposes noninterest expenses into employee- and office-related expenses. Finally, unlike similar studies in the literature, this note provides a cross-sectional pooled time series data (1986-95) that captures the changes in managerial discretion on expense preference over time. This is especially interesting for the Spanish depository 
industry, which has experienced changes in its regulatory environment and market structure during our sample period.

Overall, the evidence indicates that savings banks, i.e., mutual institutions, are more noninterest cost inefficient than commercial banks, thus supporting the presence of an expense-preference behavior. The results are stronger once estimations are adjusted for the appropriate production technology. The evidence is further supported by subsequent regression estimations where the bivariate variable representing mutual institutions report a significantly strong positive impact on noninterest and employee expense inefficiency scores. This also suggests that mutual institutions in Spain possess a certain level of inefficiency in the noninterest sector and therefore the institutions have additional ability to discard inefficiency and compete even more successfully in the depository market.

The rest of this paper is organized as follows: Section II discusses some recent analyses on organizational form and cost structure followed by a brief overview of recent developments in the Spanish banking system. Section III discusses data sources and presents the econometric frontier model estimating expense-preference structure or cost inefficiency, followed by regressions model explaining the relative role of organizational form in explaining the variability of different segments of cost inefficiency. Section IV presents the result, and section V the conclusion.

\section{Organizational Form and Cost Structure in Spanish Banking Expense Preference of Mutual Form}


Researchers have long been interested in the topic of firm activities as well as property rights of the contracting parties within an organization and their effects on managerial and owner activities and performance [Coase (1937), Jensen and Meckling (1976), Fama and Jensen (1983a, 1983b)]. A particular area of focus has been the difference of property rights associated with the mutual form of organization versus the corporate form. A mutual organization is one in which the depositors are the owners with very limited control over management. Whereas, in stock institutions, there is a separation between owners and customers, and managers are periodically monitored by owners (stockholders). It is argued that such arrangements make the managers in mutual institutions engage in various forms of expense-preference behavior that serve the managers' interest at the expense of the owners. As discussed earlier, the empirical evidence on this issue is mixed.

Mester (1989) investigated the possibility of agency problems in U.S. mutual S\&L institutions, focusing on the management's inefficient use of inputs. She argued that one should take into account the probable differences in the production technologies of mutual and stock institutions to avoid reaching inaccurate conclusions about their behavior and strategy. In an unrelated study, Mester (1993) estimated firm efficiency, assuming that mutual and stock institutions had different production technologies, finding more robust evidence. Mester (1991) reported evidence of agency problem in mutual institutions where managers were selecting an inefficient output mix. The paper also revealed that a stock institution's ability to acquire financing from the capital market could lead to differences in cost structures between the two groups. However, in a somewhat similar study, Cebenoyan et al. (1993) could not reject the null hypothesis that the coefficients on the cost frontiers were equal for mutual and stock institutions. Following Mester (1993), this note also extends the 
debate on the importance of differentiating production technology among groups of different organizational forms in the Spanish banking environment.

\section{Spanish Banking System: Recent Developments}

In the Spanish banking system (SBS), there are primarily two sectors: commercial banks and savings banks, organized as stock and mutual institutions respectively. Commercial banks were traditionally more corporate business oriented as opposed to savings banks that were involved primarily in retail services to households and smaller business entities in restricted local areas.

Regulatory reforms appeared in the SBS in order to improve bank competitiveness and their convergence with rest of European bank standards have required banks to adopt adequate new strategies. As interest rates and geographical restrictions were removed, Spanish savings banks have grown rapidly. A series of mergers reduced their numbers by nearly $35 \%$ and enabled them to operate nationwide and provide a wider range of banking services comparable to that of the commercial banks. Instead of focusing on expansion, commercial banks concentrated on adjusting their businesses to meet the new competitive market. Both types of institutions took initiatives to accommodate increased requirements of the BIS capital adequacy standards required by directives of the European Monetary Union. ${ }^{2}$

So far, the pro-competitive forces of banking liberalization appear to be strong, as banks' markups have declined in both the deposit and loan markets. Institutions that were not subject to meaningful competition previously are apparently undertaking initiatives to survive in the new environment. However, it seems that depository institutions have not made substantial reductions in their use of input (capital and labor) factors [Kumbhakar et al. (1999)]. The influence of the old banking practice is still reflected in the weight of fixed assets and office expenses, and there is 
evidence of increasing labor expenses in the industry [Hasan et al. (1999)]. This note attempts to unfold whether the organizational form plays substantial role in the excess use of factor inputs.

\section{Data and Estimation}

\section{Data}

Our data set consists of 970 observations of which 480 are commercial banks and 516 are savings banks over the $1986-95$ period. Annual data for savings and commercial bank are taken from the "Anuario de la Confederacion de Cajas de Ahorros" and "Anuario Estadistico de la Banca Española" respectively. As mentioned earlier, intense consolidation caused the number of savings banks to decline from 77 to 50 during the sample period. We were forced to delete some of the institutions due to the lack of consistent and unstained data.

Although, our focus is primarily on the noninterest expense inefficiency (expense preference), we include interest cost inefficiency given the unique ability of commercial banks to raise funds from the capital market. This type of financing capability of stock institutions may lead to differences in interest structures between the two groups [Mester (1991)]. For the Spanish banking industry, it may also provide an opportunity to capture the possible consequences of interest rate deregulation during the late 1980s as well as to understand the role of interest and noninterest rate expenditures as a strategy to attract depositors and borrowers. Basch (1987) asserts that deposit interest rates and certain noninterest expenditures may be substitutes for one another in a bank's effort to attract deposits. We investigate the noninterest cost further by separately estimating the inefficiency associated with employee and office expense components of noninterest costs.

Estimation of Cost Inefficiency. 
We used the econometric frontier approach (EFA) to estimate cost inefficiency. ${ }^{3}$ In EFA models, a cost frontier is estimated using a statistical procedure that decomposes the error term into two parts: The first captures random disturbances and is assumed to follow a symmetric normal distribution around the cost frontier; the second is assumed to capture inefficiency and is usually assumed to follow a positive half-normal distribution above the cost frontier. These measured inefficiencies may be the result of poor managerial performance (e.g., expensepreference behavior, agency problems, incompetence) or of phenomena beyond management control (e.g., local or regional economic conditions). ${ }^{4}$

We specify the cost function using the Fourier-flexible functional form, which combines a standard translog functional form with the nonparametric Fourier functional form. The translog form is a local approximation that performs well for banks close to the sample means, but can perform poorly for particularly small or large banks. In the Fourier-flexible form, trigonometric transformations of the translog variables are added so that the function globally approximates the underlying cost or revenue function over the entire range of data. Mitchell and Onvural (1992), McAllister and McManus (1993), Berger, Leusner, and Mingo (1997), Berger, Cummins, and Weiss (1997), Berger and DeYoung (1997) and DeYoung and Hasan (1998) all found that the Fourier-flexible form dominates the translog form. Use of such functional form is particularly appropriate for analyzing the Spanish banking industry which consists of institutions that have wide range of asset sizes. 
where the subscript that identifies individual banks has been dropped for simplicity. $\mathrm{C}$ is cost; $\mathrm{Y}$ is a vector of outputs, including total loans, other assets, and demand deposits; and $\mathrm{W}$ is a vector of input prices including the prices of labor, physical capital, and borrowed funds. ${ }^{6}$ The Z's are functions that rescale the $\ln \mathrm{Y}_{\mathrm{j}}$ and the $\ln \mathrm{W}_{\mathrm{m}}$ terms so that they fall on the interval $[.1 * 2 \pi, .9 * 2 \pi]{ }^{7}$

$$
\begin{aligned}
\ln C & =\alpha_{0}+\sum_{j}^{4} \beta_{j} \ln Y_{j}+\frac{1}{2} \sum_{j}^{4} \sum_{k}^{4} \beta_{j k} \ln Y_{j} \ln Y_{k}+\sum_{m}^{3} \gamma_{m} \ln W_{m} \\
& +\frac{1}{2} \sum_{m}^{3} \sum_{n}^{3} \gamma_{m n} \ln W_{m} \ln W_{n}+\sum_{j}^{4} \sum_{m}^{3} \rho_{j m} \ln Y_{j} \ln W_{m} \\
& +\sum_{j=1}^{7}\left[\delta_{j} \cos Z_{j}+\theta_{j} \sin Z_{j}\right]+\sum_{j=1}^{7} \sum_{k=1}^{7}\left[\delta_{j k} \cos \left(Z_{j}+Z_{k}\right)+\theta_{j k} \sin \left(Z_{j}+Z_{k}\right)\right] \\
& +\sum_{j=1}^{7} \sum_{k=j}^{7} \sum_{l=k}^{7}\left[\delta_{j k l} \cos \left(Z_{j}+Z_{k}+Z_{l}\right)+\theta_{j k l} \sin \left(Z_{j}+Z_{k}+Z_{l}\right)\right]+\eta
\end{aligned}
$$

The error term $\eta$ is a composite expression: $\eta=\ln U+\ln V$, where $\ln U$ captures cost inefficiency and is distributed as a truncated normal variable, and $\ln \mathrm{V}$ captures random error and is distributed as a normal variable. ${ }^{8}$

We follow Mester (1993) allowing all parameters of the model to differ between mutual (savings bank) and stock (commercial bank) institutions, i.e., it allowing the cost frontier and error structure to differ. We estimate a number of regressions of this cost function using interest cost, noninterest cost, and its employee expense component as cost variables (dependent variables).

\section{Regression Model}

Once we have attained the cost inefficiency scores from the cost function, we employ a series of Ordinary Least Squares (OLS) regressions to evaluate the potential determinants 
associated with such inefficiency. In this study, however, we are most interested on the possible influence of organizational form on different types of cost inefficiency scores. The estimates follow a specification as given below:

$$
\begin{aligned}
& \ln _{i}=\alpha_{0}+\beta_{1} * \text { ASSETS }_{\mathrm{i}}+\beta_{2} * \text { C\&CLOAN }_{\mathrm{i}}+\beta_{3} * \text { RSECURITY }_{\mathrm{i}}+\beta_{4} * \text { RETDEPOSIT }_{\mathrm{i}} \\
& +\beta_{5} * \text { EQUITY }_{\mathrm{i}}+\beta_{6} * \text { LNLOSS }_{\mathrm{i}}+\beta_{7} * \text { BRANCH }_{\mathrm{i}}+\beta_{8} * \text { ATM }_{\mathrm{i}}+\beta_{9} * \text { MUTUAL }_{\mathrm{i}}+\varepsilon_{\mathrm{i}}
\end{aligned}
$$

where $\ln \mathrm{U}_{\mathrm{i}}$ is the cost inefficiency for bank $\mathrm{I} ; \varepsilon_{\mathrm{i}}$ is a random error term; ASSET is logarithm of total assets and a proxy of size; C\&CLOAN is commercial loans and consumer loans over assets; RSECURITY is defined by the ratio of risky security of the banks over assets. These three variables are proxy for output mix and the complexity of the firm. RETDEPOSIT represents retail deposit over assets, a cheaper, traditional funding source representing liability management strategy; EQUITY and LOANLOSS over asset ratios represent the current financial conditions and strength of firms; BRANCH and ATMS are natural logarithms of the number of branch offices and ATMs, respectively, representing operational strategy; and MUTUAL is the binary variable differentiating mutuals (MUTUAL $=1)$ from stock institutions $(\mathrm{MUTUAL}=0)$.

\section{Results}

The combined inefficiency scores are reported in Table 1. Panel A represents inefficiency scores of estimations that assume a similar production technology between the two groups, and Panel B represents inefficiency scores that assume a different production technology between the

two groups. ${ }^{9}$ Column 1 represents noninterest cost inefficiency scores, followed by its office and employee expense components in columns 2 and 3, respectively. Column 4 provides interest cost 
inefficiency. In both panels, the noninterest cost inefficiency is found to be significantly higher for savings institutions compared to that of the commercial banks. ${ }^{10}$ However, the difference in inefficiency scores - 0.1268 for savings banks compared to 0.0413 for commercial banks - and its statistical significance is stronger in panel B (t-statistics 12.91) where the estimation assumed a different production technology.

The findings are also similar when noninterest expenses are decomposed into two components: office cost and employee cost. In the office expense category, the difference is small and the statistical significance of the difference is nonexistent in Panel A; however, the difference between the two groups is significant in panel B. For the employee cost estimations, saving institutions reveal a significantly higher inefficiency score than that of commercial banks in both estimates. These results are consistent with an expense-preference scenario by the mutual institutions in the Spanish banking industry. On the other hand, in the interest cost inefficiency category, savings banks report a lower inefficiency score than commercial banks, thus rejecting any competitive advantage in financing cost by stock institutions with a relatively higher access to the capital market. Later, the multivariate evidence reveals that savings banks' lower interest inefficiency is primarily driven by their dependence on cheaper retail deposits. ${ }^{11}$.

Table 2 provides multiple regression results that investigate the likely association between organizational form and other pertinent variables with different dependent variables: noninterest, interest, employee, and office cost inefficiency scores. Given that the regressions on yearly samples are not significantly different from the combined estimations, we only report regressions based on the complete sample. We employ regressions using inefficiency scores estimated under 
both assumptions of the same production technology (columns 1 and 2) and different production technology (columns 3 and 4) between the mutual and stock forms of institutions.

First, we focus on the impact and statistical significance of the bivariate 'mutual' variable on noninterest cost inefficiency reported in columns 1 and 3 of Panel A. Although the "mutual dummy" variable is positively related to the inefficiency score in column 1, the parameter however is not statistical significant. In column 3, we find a strong positive and statistically significant $(\rho=0.01)$ relationship between the mutual parameter and variability of the inefficiency score. Interestingly, the model statistics (R-squared) for the regression in column 3 was significantly stronger - $62.85 \%$ versus $12.48 \%$ - than the model statistics of the regression in column 1 . This suggests a superior goodness of fit for the regression that uses inefficiency scores based on a separate technology between the two groups (column 3). In interest cost inefficiency regressions, the evidence is somewhat consistent with previous findings based on univariate statistics as the "mutual" variable reports an inverse relationship with the dependent variable in both estimates. Although the parameters of the variable are not statistically significant, the evidence at least confirms that commercial banks do not have any competitive advantage in financing cost.

We repeat a similar estimation using noninterest cost inefficiency components - employee cost and office cost inefficiency scores - as dependent variables. The employee cost regressions show stronger model statistics relative to the office cost regressions. Evidence does that the mutual variable has a significant impact on any of the dependent variables in estimates based on the assumption of similar technology. However, under the different technology assumption, we see that the mutual parameter has a positive and statistically significant impact on the employee 
cost inefficiency (column 3). These findings are consistent with an expense- preference-prone mutual form of organizations, especially when estimates are based on a different technology assumption for the two types of organization. ${ }^{12}$

Focusing on other parameters, we find that asset variable portrays a positive sign in all estimates, indicating that larger institutions are more associated with cost inefficiency and thus are more likely to expense-preference-prone depository institutions irrespective of the form of organizations considered. Traditional institutions with a higher dependence on retail deposits as a funding source are found to be less associated with employee inefficiency or expense- preference behavior. The branch variable indicates that the higher network strategy is creating higher inefficiency in all noninterest-related regressions as more capital and labor expenses are associated with such decisions. However, in respect to interest cost inefficiency estimates, the branching strategy apparently helps to lower the inefficiency level. Aggressive institutions with higher risky assets in their portfolios are less associated with inefficiency.

Overall, there is a strong and positive correlation between mutual variable and noninterest cost and employee cost inefficiency, especially when estimates of efficiency scores are corrected for a different production technology, thereby indicating a higher expense-preference behavior by the savings banks. However, the evidence is not as overwhelming when we investigate the sample assuming both forms of organizations have a similar production technology. A likelihood ratio test of the restricted model (same production frontier) versus (nonrestricted model (separate or different production technology) indicated that the restricted model is strongly rejected by the data at the 0.005 level of significance with a likelihood ratio test statistic of 130.91. Given this 
result and similar conclusions in Mester (1993), we gave more importance to the result based on a separate production technology.

\section{CONCLUSION}

This paper provides additional evidence in the existing debate on expense preference in the banking industry. It uses data from the Spanish depository industry which has both mutual and stock types of institutions. By introducing a stochastic frontier analysis in estimating the bestpracticed expense-preference behavior, we have attempted to investigate the role of organizational forms in determining the variability of expense inefficiency. Assuming that mutual and stock institutions follow different production technologies, we find significant differences in noninterest and labor (employee) cost categories between both types of institutions. Evidence suggests that savings banks are more noninterest-inefficient (or higher expense-preference) than the commercial banks. We also expand our study with a multivariate analysis to find a possible correlation between inefficiency scores and organizational form as well as certain institutionsspecific lending, funding, and operational activities and strategies. The evidence on expensepreference behavior is consistent with previous findings, especially for the sample where inefficiency scores are estimated assuming a different production technology.

Interestingly, despite higher expense preferences, the savings banks apparently recorded a higher return on assets and increasing market share relative to the commercial banks, especially during the post-deregulatory $1992-95$ period. ${ }^{13}$ It is plausible that the new opportunities and intense market competition in the deregulatory environment caused higher noninterest expenses. However, one may also interpret such developments as a deliberate strategy by the savings banks to provide higher salaries and incentives to workers (pay-for-performance) to compete with commercial banks in 
the newly deregulated markets. Further research is warranted in this area in order to reach any definite conclusions. 


\section{References}

Aigner, D.J., Lovell, C.A., and P. Schmidt. 1977. "Formulation and Estimation of Stochastic Frontier Production Function Models," Journal of Econometrics 6: 21-37.

Awh, R. and W. Primeaux. 1985. "Managerial Discretion and Expense Preference Behavior," Review of Economics and Statistics, 67: 224-231.

Basch, Donald L. 1987. Rivalry and Expense-Preference Behavior Among Savings Banks: The Role of Deposit Rate Ceilings," Journal of Economics and Business, 39:225-238.

Bauer, Paul W. 1990. "Recent Developments in the Econometric Estimation of Frontiers," Journal of Econometrics, 46: 39-56.

Berger, Allen N. 1993. "Distribution-Free Estimates of Efficiency in the U.S. Banking Industry and Tests of the Standard Distributional Assumptions," Journal of Productivity Analysis 4: 261-292.

Berger, Allen and Robert DeYoung. 1997 "Problem Loans and Cost Efficiency in Commercial Banks," Journal of Banking Finance, 21, 919-944.

Berger, Allen N., Leusner, J.H., and John J. Mingo. 1997. "The Efficiency of Bank Branches," Journal of Monetary Economics, 40:141-162.

Berger, Allen N., Cummins, J. David, and Mary A. Weiss. 1997. "The Coexistence of Multiple Distribution Systems for Financial Services: The Case of Property-Liability Insurance," Journal of Business, 70:515-546.

Berger, Allen N., and David B. Humphrey. 1997. "Efficiency of Financial Institutions: International Survey and Directions of Future Research," European Journal of Operation Research, 98:175-212.

Berger, Allen N., William C. Hunter, and Stephen G. Timme. 1993. “The Efficiency of Financial Institutions: A Review And Preview of Research Past, Present, and Future,” Journal of Banking Finance, 17(2-3):221-250.

Blair, D. and D. Placone. 1988. "Expense Preference Behavior, Agency Cost, and Firm Organization," Journal of Economics and Business, 40:1-15.

Canals, Jordi. 1997. Universal Banking: International Comparisons and Theoretical Perspectives, Oxford University Press, Oxford.

Coase, Ronald. 1937. "The Nature of the Firm," Economica 4:386-405 
Carhill, Michael and Iftekhar Hasan. 1997. "Mutual to Stock Conversion and Thrift Performance," Financial Review, 32(3):545-568.

Cebenoyan, A.S., Elizabeth Cooperman, Charles A. Register and Sylvia Hudgins. 1993. "The Relative Efficiency of Stock Versus Mutual S\&Ls: A Stochastic Cost Frontier Approach," Journal of Financial Services and Research, 7:151-170.

DeYoung, Robert and Iftekhar Hasan. 1998. "The Performance of De novo Commercial Banks: A Profit Efficiency Approach,” Journal of Banking and Finance, 22:565-587.

Edwards, F. 1977. "Managerial Objectives in Regulated Industries: Expense Preference Behavior in Banking," Journal of Political Economy, 85:147-162.

Fama, Eugene, and Jensen, Michel. 1983a. "Separation of Ownership and Control," Journal of Law and Economics, 26:301-325.

Fama, Eugene, and Jensen, Michel. 1983b. "Agency Problem and Residual Claims," Journal of Law and Economics, 26:3027-349.

Fields, J.A. 1988. "Expense Preference Behavior in Mutual Life Insurers," Journal of Financial Services Research, 1:113-129.

Hannan, T. H. 1979. "Expense-Preference Behavior in Banking: A Reexamination," Journal of Political Economy, 87:891-895.

, F. Mavinga. 1980. "Expense Preference and Managerial Control: The Case of Banking Firm," The Bell Journal of Economics, 11:671-682.

Hasan, Iftekhar, W. C. Hunter, and Ana Lozano-Vivas. 1999. " Deregulation, Strategy, Bank Performance And Efficiency: Spanish Experience." in in European Union Banking Issues: Historical and Contemporary Perspectives, Edited by Irene Finel-Henigman (forthcoming), JAI Press.

Jensen, Michael C. and William H. Meckling. 1976. "Theory of The Firm: Managerial Behavior, Agency Costs, and Ownership Structure," Journal of Financial Economics, 3:305-360.

Jondrow, J., C.A. Lovell, I.S. Materov, and P. Schmidt. 1982. "On Estimation of Technical Inefficiency in the Stochastic Frontier Production Function Model," Journal of Econometrics, 19: 233-238.

Kumbhakar, S., Lozano-Vivas, A., Lovell, K. and I. Hasan. 1999. "The Effects of Deregulation on the Performance of Financial Institutions: The Case of Spanish Savings Banks," Working Paper, University Of Texas. 
Leibenstein, H. 1966. "Allocative Efficiency vs. 'X-Efficiency," American Economic Review, 56:392415 . , 1975. "Aspects of X-Efficiency Theory of Firm." The Bell Journal of Economics, 6:580-606.

Lozano-Vivas, A. 1998. "Efficiency and Technical Change for Spanish Banks," Applied Financial Economics, 8, 289-300

McAllister, Patrick H., and Douglas McManus. 1993. "Resolving the Scale Efficiency Puzzle in Banking," Journal of Banking and Finance, 17: 389-405.

Mester, L. 1989. "Testing for Expense Preference Behavior: Mutual versus Stock Savings and Loans," RAND Journal of Economics, 20(4): 483-498.

Mester, L. 1991. "Agency Costs among Savings and Loans," Journal of Financial Intermeditation, 1: 257-278.

Mester, L. 1993. "Efficiency in the Savings and Loan Industry," Journal of Banking and Finance, 17(2-3):267-286.

Mitchell, Karlyn, and Nur M. Onvural, 1992. "Economies of Scale and Scope at Large Commercial Banks: Evidence from the Fourier Flexible Functional Form," North Carolina State University, working paper, November 1992.

Rhoades, S.A. 1980. "Monopoly and Expense Preference Behavior: An Empirical Investigation of a Behaviorialist Hypothesis," Southern Economics Journal, 47:419-432.

Smirlock, M. and W. Marshall. 1983. "Monopoly Power and Expense Preference Behavior: Theory and Evidence to the Contrary," Bell Journal of Economics, 14:166-178.

Stansell, S.R. and D.R. Hollas. 1990. "An examination of the Relative Economic Efficiency of Mutual vs. Stock Savings Institutions," The Journal of Real Estate Finance and Economics, 3:73-89.

Stevenson, Rodney E. 1980. "Likelihood Functions for Generalized Stochastic Frontier Estimation," Journal of Econometrics, 13: 58-66.

Verbrugge, J. E. and S. J. Goldstein. 1981. "Risk-Return and Managerial Objectives: Some Evidence From the Savings and Loan Industry," Journal of Financial Research, 4:45-58. , and J. S. Jahera Jr. 1981. "Expense-Preference Behavior in the Savings and Loan Industry,"

Journal of Money, Credit, and Banking, 13(4):465-476.

Williamson, O. E. 1963. "Managerial Discretion and Business Behavior," American Economic Review, 53:1032-1057. 


\section{Table 1}

Mean Cost Inefficiency Scores of Spanish Depository Institutions

\begin{tabular}{|c|c|c|c|c|}
\hline Sample & $\begin{array}{l}\text { Noninterest } \\
\text { Cost } \\
\text { Inefficiency }\end{array}$ & $\begin{array}{l}\text { Office Cost } \\
\text { Inefficiency }\end{array}$ & $\begin{array}{l}\text { Employee Cost } \\
\text { Inefficiency }\end{array}$ & $\begin{array}{l}\text { Interest Cost } \\
\text { Inefficiency }\end{array}$ \\
\hline \multicolumn{5}{|c|}{ PANEL A } \\
\hline \multicolumn{5}{|c|}{ Estimate of Groups Assuming Same Production Technology } \\
\hline & 1 & 2 & 3 & 4 \\
\hline $\begin{array}{c}\text { Commercial } \\
\text { Banks [Stock } \\
\text { Institutions] }\end{array}$ & $\begin{array}{c}0.1134 * * \\
(0.0960)\end{array}$ & $\begin{array}{c}0.0738 \\
(0.0393)\end{array}$ & $\begin{array}{c}0.1271 * * \\
(0.0732)\end{array}$ & $\begin{array}{c}0.0715 * * \\
(0.0511)\end{array}$ \\
\hline $\begin{array}{c}\text { Savings Banks } \\
\text { [Mutual } \\
\text { Institutions] }\end{array}$ & $\begin{array}{c}0.1455 \\
(0.1281)\end{array}$ & $\begin{array}{c}0.0798 \\
(0.0506)\end{array}$ & $\begin{array}{c}0.1489 \\
(0.0711)\end{array}$ & $\begin{array}{c}0.0402 \\
((0.034)\end{array}$ \\
\hline $\begin{array}{c}\text { Combined } \\
\text { Sample } \\
\end{array}$ & $\begin{array}{c}0.1310 \\
(0.1149) \\
\end{array}$ & $\begin{array}{c}0.0764 \\
(0.0440) \\
\end{array}$ & $\begin{array}{c}0.1370 \\
(0.1277) \\
\end{array}$ & $\begin{array}{c}0.0697 \\
(0.0460) \\
\end{array}$ \\
\hline \multicolumn{5}{|c|}{ PANEL B } \\
\hline \multicolumn{5}{|c|}{ Estimate of Groups Assuming Different Production Technology } \\
\hline $\begin{array}{c}\text { Commercial } \\
\text { Banks }\end{array}$ & $\begin{array}{l}0.0413 * \\
(0.0130)\end{array}$ & $\begin{array}{l}0.0354 * * * \\
(0.0312)\end{array}$ & $\begin{array}{l}0.0864 * \\
(0.0867)\end{array}$ & $\begin{array}{l}0.0858 * \\
(0.0741)\end{array}$ \\
\hline $\begin{array}{c}\text { Savings } \\
\text { Banks }\end{array}$ & $\begin{array}{c}0.1268 \\
(0.0507)\end{array}$ & $\begin{array}{c}0.0403 \\
(0.0187)\end{array}$ & $\begin{array}{c}0.1404 \\
(0.0691)\end{array}$ & $\begin{array}{c}0.031 \\
(0.0192) \\
\end{array}$ \\
\hline
\end{tabular}

Note: $* * *, * * *=$ Significantly different from savings banks at the 1,5 , and $10 \%$ significance level, respectively. 
Table 2

Variables Associated with Inefficiency Scores Ordinary Least Square Regressions

\begin{tabular}{|c|c|c|c|c|}
\hline \multicolumn{5}{|c|}{ PANEL A } \\
\hline \multirow{3}{*}{$\begin{array}{c}\text { Independent Variables } \\
\text { or Ratios } \\
\end{array}$} & \multicolumn{4}{|c|}{ Dependent Variables } \\
\hline & \multicolumn{2}{|c|}{ Same Technology } & \multicolumn{2}{|c|}{ Different Technology } \\
\hline & $\begin{array}{l}\text { Noninterest Cost } \\
\text { Inefficiency }\end{array}$ & $\begin{array}{l}\text { Interest Cost } \\
\text { Inefficiency }\end{array}$ & $\begin{array}{l}\text { Noninterest Cost } \\
\text { Inefficiency }\end{array}$ & $\begin{array}{l}\text { Interest Cost } \\
\text { Inefficiency }\end{array}$ \\
\hline & 1 & 2 & 3 & 4 \\
\hline Intercept & -0.109 & $-0.370 *$ & $0.099 *$ & -0.026 \\
\hline Log of Assets & $0.104 *$ & $0.211 *$ & $0.027 *$ & $0.100 *$ \\
\hline $\begin{array}{c}\text { Commercial and } \\
\text { Consumer Loan Ratio }\end{array}$ & $0.098 *$ & $0.045 *$ & $-0.035 *$ & $-0.043 *$ \\
\hline Risky Security Ratio & $-0.010 * *$ & $-0.006 * *$ & $-0.010 * *$ & $-0.008 * *$ \\
\hline Retail Deposit Ratio & $0.044 *$ & $-0.172 *$ & $0.001 *$ & $-0.051 *$ \\
\hline Equity Ratio & $-0.031 * *$ & $-0.078 * *$ & $0.020 *$ & -0.001 \\
\hline Loan Loss Ratio & $0.010 * *$ & $0.029 *$ & $0.001 *$ & $0.010 *$ \\
\hline Log of Branch & $-0.003 *$ & $-0.169 *$ & $0.075 *$ & $-0.010 *$ \\
\hline Log of ATM & $-0.003 * *$ & -0.001 & $0.001 *$ & -0.001 \\
\hline \multirow[t]{2}{*}{ Mutual Dummy } & 0.004 & -0.0001 & $0.003 * *$ & -0.001 \\
\hline & \multicolumn{4}{|c|}{ Model Statistics } \\
\hline Adjusted R-squared & $12.48 \%$ & $39.90 \%$ & $62.85 \%$ & $30.26 \%$ \\
\hline
\end{tabular}

\begin{tabular}{|c|c|c|c|c|}
\hline \multicolumn{5}{|c|}{ PANEL B } \\
\hline \multirow{4}{*}{$\begin{array}{c}\text { Independent Variables } \\
\text { or Ratios }\end{array}$} & \multicolumn{4}{|c|}{ Dependent Variables } \\
\hline & \multicolumn{2}{|c|}{ Same Technology } & \multicolumn{2}{|c|}{ Different Technology } \\
\hline & $\begin{array}{c}\text { Employee Cost } \\
\text { Inefficiency }\end{array}$ & $\begin{array}{l}\text { Office Cost } \\
\text { Inefficiency }\end{array}$ & $\begin{array}{c}\text { Employee Cost } \\
\text { Inefficiency }\end{array}$ & $\begin{array}{l}\text { Office Cost } \\
\text { Inefficiency }\end{array}$ \\
\hline & 1 & 2 & 3 & 4 \\
\hline Intercept & $-0.184 *$ & $0.134 *$ & 0.004 & -0.142 \\
\hline Log of Assets & $0.317 *$ & $0.017 *$ & $0.175 *$ & $0.051 *$ \\
\hline $\begin{array}{c}\text { Commercial and } \\
\text { Consumer Loan Ratio }\end{array}$ & $-0.248 *$ & $-0.020 *$ & -0.141 & $-0.039 *$ \\
\hline Risky Security Ratio & $-0.072 *$ & -0.001 & $-0.038 *$ & $-0.010 *$ \\
\hline Retail Deposit Ratio & $-0.024 *$ & $0.009 * *$ & $-0.010 * *$ & -0.001 \\
\hline Equity Ratio & $0.021 *$ & 0.004 & $0.027 *$ & -0.001 \\
\hline Loan Loss Ratio & 0.003 & $0.005 *$ & $0.002 * *$ & $0.002 *$ \\
\hline Log of Branch & 0.001 & $-0.032 *$ & $0.048 *$ & -0.003 \\
\hline Log of ATM & $0.004 *$ & $0.001 *$ & $0.001 * *$ & -0.0002 \\
\hline \multirow[t]{2}{*}{ Mutual Dummy } & 0.001 & 0.004 & $0.005 * *$ & 0.001 \\
\hline & \multicolumn{4}{|c|}{ Model Statistics } \\
\hline Adjusted R-squared & $28.23 \%$ & $8.06 \%$ & $48.84 \%$ & $20.79 \%$ \\
\hline
\end{tabular}

Note: All ratios are relative to assets. Log means natural logarithm. $* *$ and $*=$ coefficients are significant at the 1 or $5 \%$ significance level, respectively. 


\section{Endnotes}

${ }^{1}$ See Berger et al. (1993) and Berger and Humphrey (1997) for an extensive review of the efficiency literature in the banking industry.

${ }^{2}$ For more details on the developments of the banking system in Spain, see Canals (1997).

3 The econometric, or "stochastic," frontier approach was introduced by Aigner et al. (1977), and was made tractable by Jondrow et al. (1982). Bauer (1990) offers an overview of these methods.

${ }^{4}$ See Cebenoyan et al. (1993) and Berger et al. (1993).

${ }^{5}$ We estimated the cost equation using maximum likelihood techniques, and imposed the standard symmetry and homogeneity restrictions on the translog portion of the model. Factor share equations were omitted because application of the usual cross-equation restrictions would impose the assumption that the given input proportions were the allocatively efficient ones [see Berger 1993, p. 266].

${ }^{6}$ The price of labor equals salaries and benefits divided by the number of full-time equivalent workers. The price of physical capital equals expenditures on equipment and premises divided by the book value of physical assets. The price of borrowed funds equals total interest expense divided by total borrowed funds.

${ }^{7}$ See Berger et al. (1997) for a derivation of, and a justification for, this truncation.

${ }^{8}$ Stevenson (1980) has shown that the assumption of a truncated normal inefficiency distribution is more general and more flexible than the assumption of a half-normal distribution. Berger and DeYoung (1997) show that the truncated normal distribution results in lower estimates of average inefficiency for banks than does the halfnormal, but that the rank efficiency order of banks remains virtually identical across distributions.

${ }^{9}$ Separate production technology means it allows all the parameters of the model to differ between mutual (savings banks) and stock (commercial banks) institutions, i.e., it allows the cost frontier and error structure to differ [Mester (1993)].

10 These results are consistent with Lozano-Vivas (1998).

11 Focusing further on the cost inefficiency scores on a yearly basis, we find results to be consistent with the combined sample and they are not reported in the text. Over the entire period, the savings banks show a higher noninterest and employee cost inefficiency and lower interest cost inefficiency than the commercial banks. The inefficiency scores for the sample savings banks in the post 1992 period show a minor decline. This may be indicating an improvement in reducing noninterest cost inefficiency after the initial and a little unstable deregulation experience during the 1986-91 period. This could also be the result of an increased competitive environment where managers were forced to lower, among other costs, the noninterest expenses. All these estimates are available upon request.

${ }^{12}$ Mester (1993) revealed that the differences in total cost inefficiency between the mutual and stock U.S. thrifts cease to exist when a separate production technology is used.

${ }^{13}$ No descriptive statistics is reported in the text of this note; however, they are available upon request 